Hydrol. Earth Syst. Sci., 17, 2797-2807, 2013

www.hydrol-earth-syst-sci.net/17/2797/2013/

doi:10.5194/hess-17-2797-2013

(C) Author(s) 2013. CC Attribution 3.0 License.

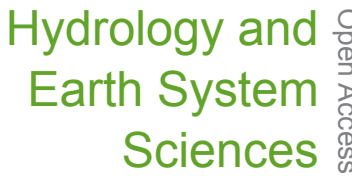

\title{
Simulation of hydrological processes in the Zhalong wetland within a river basin, Northeast China
}

\author{
X. Q. Feng ${ }^{1,2}$, G. X. Zhang ${ }^{1}$, and Y. Jun $\mathrm{Xu}^{3}$ \\ ${ }^{1}$ Northeast Institute of Geography and Agroecology, Chinese Academy of Sciences, Changchun, 130012, China \\ ${ }^{2}$ Liaoning Province Hydrology and Water Resources Survey Bureau, Shenyang, 110003, China \\ ${ }^{3}$ School of Renewable Natural Resources, Louisiana State University and LSU Agricultural Center, Baton Rouge, \\ LA 70803, USA
}

Correspondence to: G. X. Zhang (zhgx@neigae.ac.cn)

Received: 5 December 2012 - Published in Hydrol. Earth Syst. Sci. Discuss.: 19 December 2012

Revised: 7 April 2013 - Accepted: 14 May 2013 - Published: 16 July 2013

\begin{abstract}
Zhalong National Nature Preserve is a large wetland reserve on the Songnen Plain in Northeast China. Wetlands in the preserve play a key role in maintaining regional ecosystem function and integrity. Global climate change and intensified anthropogenic activities in the region have raised great concerns over the change of natural flow regime, wetland degradation and loss. In this study, two key hydrologic components in the preserve, water surface area and water volume, as well as their variations during the period 19852006, were investigated with a spatially-distributed hydrologic modeling system (SWAT). A wetland module was incorporated into the SWAT model to represent hydrological linkages between the wetland and adjacent upland areas. The modified modeling system was calibrated with streamflow measurements from 1987 to 1989 and was validated for the period 2005-2006. The calibration achieved a Nash efficiency coefficient $\left(E_{\mathrm{ns}}\right)$ of 0.86 , and the validation yielded an $E_{\mathrm{ns}}$ of 0.66 . In the past $20 \mathrm{yr}$, water surface area in the Zhalong wetland fluctuated from approximately $200 \mathrm{~km}^{2}$ to $1145 \mathrm{~km}^{2}$ with a rapid decreasing trend through the early 2000s. Consequently, water volume decreased largely in the preserve, especially in the dry seasons. The situation changed following the implementation of a river diversion in 2001. Overall, the modeling yielded plausible estimates of hydrologic changes in this large wetland reserve, building a foundation for assessing ecological water requirements and developing strategies and plans for future water resources management within the river basin.
\end{abstract}

\section{Introduction}

Wetlands cover $6 \%$ of the earth's land surface and are important ecosystems (OECD, 1996). Hydrological regimes and water resources in the wetlands around the world have been greatly altered by human activities and global climate change, which has raised great concerns from the scientific communities, general public, and government agencies (Burkett and Kusler, 2000; Acreman et al., 2009; Milzow et al., 2010; Moradkhani et al., 2010). The Zhalong wetland, a $2100 \mathrm{~km}^{2}$ wetland preserve designated as one of the Wetlands of International Importance by the Ramsar Convention, plays an important role in maintaining the ecosystem balance within the Songnen Plain in Northeast China (Yin et al., 2006). Since the 1950s, precipitation and riverine inflow in the area have declined, resulting in the change of average open surface-water depth in the Zhalong wetland from about $0.75 \mathrm{~m}$ in September 1998 to less than $0.05 \mathrm{~m}$ in April 2001 (Tong et al., 2012). Consequently, the change has caused degradation and loss of many wetlands in the Zhalong wetland preserve (Han et al., 2007). In 2001, the Chinese government launched an "ecological water diversion" project to bring water from the Nenjiang River into the Zhalong wetland. However, it is not clear when and how much water should be diverted. A good understanding of hydrological variability in the Zhalong wetland is needed to develop effective management strategies and plans.

Hydrology is a key factor affecting wetland systems. The hydrological processes influence biogeochemical cycles, control the structure and functions of wetland ecosystems, 
affect soil salinity, soil microbial activity and nutrient availability, and regulate the species composition, species richness, primary production and organic matter accumulation. Information on hydrologic characteristics is therefore fundamental for effective ecosystem restoration, which demands knowledge of wetland's geomorphologic, biological, physical and chemical characteristics (Mitsch and Gosselink, 2000). In the Zhalong wetland, field monitoring of long-term hydrologic conditions does not exist and spatial coherence between open water surface and wetland water storage is unknown. On the other hand, collection of such data across the vast wetland preserve will be time consuming and costly. Hydrological modeling provides a means to help understand wetland hydrological processes of this area under the influence from human activities and climate changes.

Concerning the previous studies of hydrological modeling, Padmanabhan and Bengtson (2001) applied the HEC-1 model (USACE, 1982) to assess the influence of wetlands on flooding in their study conducted in the North Dakota Maple River and Wile Rice River watersheds in the United States. Vining (2002) incorporated a wetland hydrology subroutine into the PRMS model (Carey and Simon, 1984) to simulate the hydrological processes and the water stored in the wetlands of the Starkweather Coulee subbasin from 1981 to 1998. Bradley (2002) used a model, which is developed using MODFLOW, to simulate the annual water table of a floodplain wetland. X. X. Wang et al. (2010) modified the wetland module in SWAT (Arnold et al., 1998) to simulate the artificial water input to the QingDianWa depression. In their simulation study on streamflow in the upper portion of the Otter Tail River watershed (Wang et al., 2008), wetlands were incorporated in the SWAT model using a "hydrologic equivalent wetland (HEW)" concept. In the above studies, wetlands were aggregated as a subbasin or as a hydrologic response unit (HRU), and were deemed as flow diversions, synthetic wetlands or hydrologic equivalent wetlands. The simulation results demonstrated that the aggregation based on HRU using the HEW concept was a useful approach.

This present study has utilized this approach, taking into account the flow exchanges between wetlands and river channels, and was modified the wetland module in the SWAT model to simulate hydrological processes of the Zhalong wetland. Using the simulated streamflow, we established the hydrological connectivity between watershed drainage areas and wetlands, and analyzed the wetland hydrological responses to watershed hydrological processes. Through building a GIS framework in a form conducive to spatial analysis on a sub-watershed scale, the modeling system provides the basis for future calculation of ecological water requirements and effective river water diversion for the entire Zhalong wetland area.

\section{Zhalong wetland}

\subsection{Description of the study area}

The Zhalong wetland is located on the west Songnen Plain, in the lower reaches of the Wuyuer and Shuangyang Rivers, Northeast China (Fig. 1). Covering an area of about $2100 \mathrm{~km}^{2}$, the Zhalong wetland is the largest national nature reserve in Northeast China. Marsh, lake and paddy field are the main wetland types in Zhalong, with marshes occupying $80-90 \%$ of the entire area (Han et al., 2007). These wetlands are important to the well-being of a number of wildlife species, especially endangered crane (e.g. red-crowned crane and Siberian white-napped crane) and waterfowl species (e.g. herons) (Qiu et al., 2005; Li et al., 1998, 1999). For conservation management, the Zhalong wetland is divided into a central zone, a buffer zone and an experimental zone based on their ecological and environmental functionalities.

Topography of the area is very flat in the south, gentle to slightly rolling in the center, and somewhat more rolling in the north. Average elevation of this area is approximately $144 \mathrm{~m}$ above sea level. Soils in the Zhalong wetland are dominated by swamp soil (45\%), meadow soil (46\%) and aeolian sandy soil $(6 \%)(\mathrm{Wu}, 1999)$. The study area contains four different vegetation communities, among which reed marsh covers $80-90 \%$ of the total area with thousands of wetlands scattered across the landscape.

The climate of the Zhalong wetland is characterized by a temperate, continental monsoon climate with occasional extremes of temperature and precipitation. Average monthly temperatures range from $-19.5^{\circ} \mathrm{C}$ in January to $23.0^{\circ} \mathrm{C}$ in July with an annual mean of $3.9^{\circ} \mathrm{C}$. Average annual precipitation in the area is about $411 \mathrm{~mm}$, much of which (85\%) occurs during the months from June to September, which is defined the rainy season. Feng et al. (2011) and Feng and Zhang (2010) used Mann-Kendall tests to assess significance of the long-term trend in temperature and precipitation for the Zalong wetland area. They found that, based on the $Z_{c}$ values of the Mann-Kendall test, annual mean temperatures in the Zalong wetland had a significant increasing trend $\left(Z_{c}=4.4\right)$ from 1951 to 2010 , especially in the spring season, and that annual precipitations showed a slight, not significant decreasing trend $\left(Z_{c}=-0.06\right)$ over the past $50 \mathrm{yr}$. During 1999 to 2002, average annual precipitation decreased to about $350 \mathrm{~mm}$. Multi-annual mean evaporation from water surface and evapotranspiration from reed were $1280 \mathrm{~mm}$ and $897 \mathrm{~mm}$, respectively (Feng and Zhang, 2010). Annual streamflow of the study area decreased since 1970s with a significant decreasing trend $\left(Z_{c}=-1.96\right)$, which was attributed to both climate change and human activities (Feng and Zhang, 2010). 


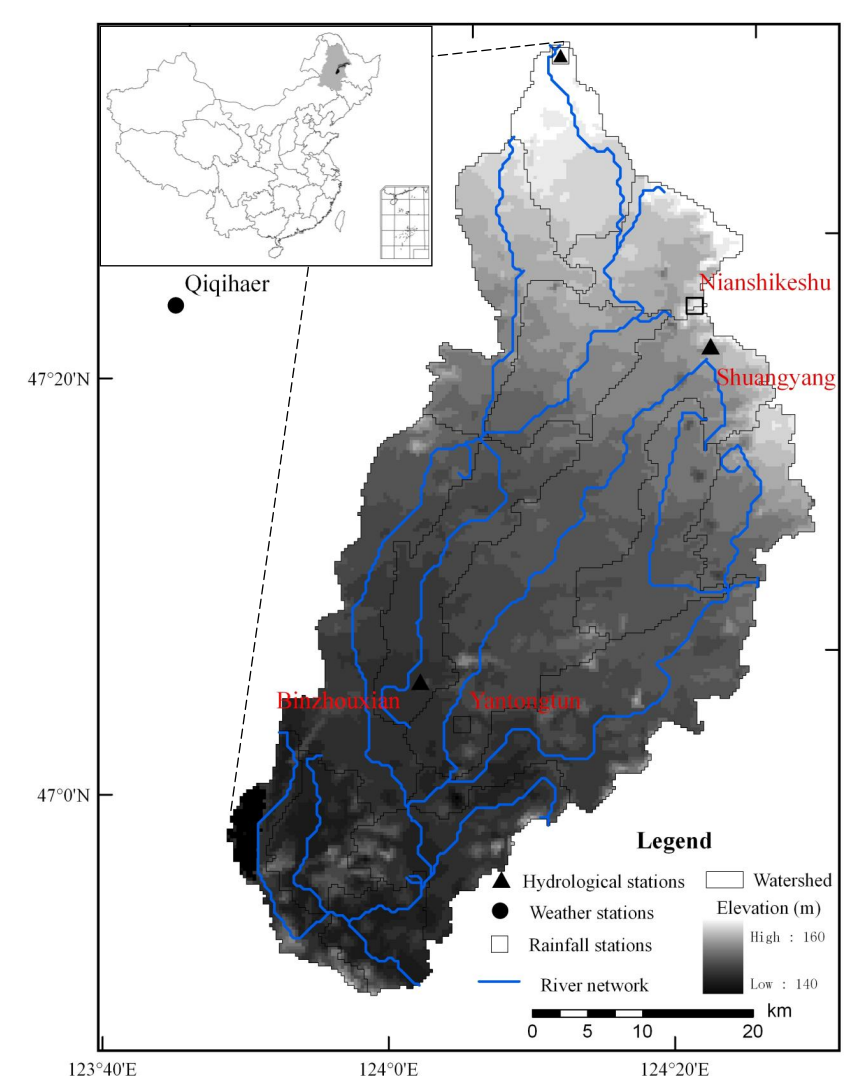

Fig. 1. Location, elevation, hydrological and weather stations, and subbasin division of the Zhalong wetland in Northeast China.

\subsection{Hydrological characteristics of the Zhalong wetland}

Hydrological characteristics of the Zhalong wetland have been well documented (Liu and Xu, 2006; Zhou et al., 2008; $\mathrm{Xu}$ et al., 2008; Wang et al., 2006). In this paper, some hydrological processes relevant to this modeling study are presented. Precipitation input in the area presents the main source sustaining the wetlands. In addition, the Zhalong wetland receives inflow from the upstream Wuyuer River as well as diverted water from the Nenjiang River. Quantity of the inflow from river diversion is highly variable affected by management decisions, for instance, with no supply during 1989 to 2000. From the spring of 2001 to 2008, a total of 931.9 million cubic meters of external water resource have been brought to the Zhalong wetland through the Nenjiang River diversion project since. Flow of the Wuyuer River that naturally feeds the Zhalong wetland is also regulated by water management measures in the basin. The river enters into the wetland area at Long'anqiao station, with a variable velocity ranging from 0.01 to $0.39 \mathrm{~m} \mathrm{~s}^{-1}$ and a variable stream width of $4-28 \mathrm{~m}$, which affects wetland conditions in the area. Channels in the wetlands are flanked by vegetation (reeds and sedges), which may retain and store the water flows. Free exchanges of waters occur between channels and surrounding wetlands when the water level is high. Channels in the study area are not well developed, especially in the lower reach where the channels lose their continuity and integrity, and take the form of often disconnected stretches with variable width and length.

Pedologically, much of the Zhalong wetland is gleization mire. The upper portion of gleization mire is a sod layer that consists of plants roots and residues. This layer has few mineral particles, high porosity, and a sponge-like texture with high saturated water content and available water capacity. These wetlands act as spongy reservoirs capable of absorbing water during the rainy seasons and releasing it slowly during the dry seasons (Krecek and Haigh, 2006). According to previous studies (Wang and Zhang, 2007; Xu et al., 2008), groundwater is mainly recharged by river and surface water. The substrates of the wetlands have higher viscosity and low permeability (typically $0.5 \mathrm{~mm} \mathrm{~d}^{-1}$ ), which makes the exchange between surface water and groundwater slow. Surface-water flow is also slow due to the flat topography and surface storage. These characteristics determine the important hydrological functions of conveyance, storage and retention of the wetlands.

\section{Materials and methods}

\subsection{Data acquisition}

High resolution digital elevation model (DEM) is the basic data for simulation of hydrological processes, which provides topographic information for the delineation of subbasins and extraction of the channel network. In this study, we first applied 3229 elevation points and contours extracted from 1:10000 topographic maps to create the triangulated irregular network (TIN); we then created $30 \mathrm{~m}$ spatial resolution DEMs. The minimal elevation interval of these points was $0.1 \mathrm{~m}$, which satisfies the resolution needed in the plain area. Due to the flat terrain in the Zhalong wetland, water flow disperses after entering wetlands, with variable flow velocity and direction. Therefore, the hydrological connectivity in these wetlands is complex. In order to better partition hydrological units, the channel network was created by digitalizing the real flow path acquired by field monitoring (Fig. 1). The digitized channel network was then used as the reference surface-water drainage network for subbasin delineation.

Climate data requirements for the SWAT model include daily records on precipitation, maximum and minimum temperature, relative humidity, wind speed and solar radiation. These data were collected from the Qiqihaer weather station for the period from 1985 to 2006. Additional daily precipitation data were obtained from three national rainfall gauge stations including Yantongtun, Nianshikeshu, and Long' anqiao (Fig. 1). Spatially referenced data on land use, soils and hydrologic characteristics of the study 
area were derived from Landsat ${ }^{\mathrm{TM}}$ images (Figs. 2 and 3), soil survey publications, and other sources of digital data and field monitoring. Stream inflow and outflow were obtained from records at the Long'anqiao station (inflow), Shuangyang station (inflow), and Binzhouxian station (outflow). Long' anqiao station and Binzhouxian station had disconnected monitoring periods with available data for 19681977 and 1971-1989, respectively, and after 2005 when the two stations resumed monitoring. For the period with missing data, simulated streamflow of the Long'anqiao station was used as inflow to the Zhalong wetland, as a previous study (Feng et al., 2010) found that the SWAT model produced reasonable results in simulating the streamflow change in the Wuyuer River Basin.

\subsection{Development of the wetland module in SWAT}

SWAT is a physically based model developed to continuously simulate hydrological processes over long periods (Arnold et al., 1998). SWAT partitions a watershed or river basin into subbasins that are connected by surface flows (Neitsch et al., 2002). Each subbasin can be further divided into one or more hydrological response units (HRUs) based on topography, land-use, and soil types. A HRU is the basic spatial unit of hydrological simulation and water budget for surface, soil, and ground water. SWAT treats wetlands as water bodies within subbasins (Arnold et al., 2001; Neitsch et al., 2002) and allows one wetland to be modeled for each subbasin, which does not consider the unique hydrological characteristics of wetlands and flow exchanges between wetlands and river channels. Wetland is the dominant land cover type in the study area and serves important hydrological functions. Therefore, we modified the wetland module and incorporated the modified version into SWAT to simulate hydrological processes of the entire study area, including wetlands and other land cover types.

\subsubsection{Partition of hydrological units}

High resolution DEM and digital river network were used to delineate watersheds and subbasins of the Zalong Wetand. The boundaries were determined by trial and error to ensure that delineated drainage channels closely matched digital channel network. Because of the flat terrain and the difficulty in automatic boundary delineation, actual boundaries of the subbasins in the Zhalong wetland were defined manually. There were some inconsistencies between actual boundary and the boundary automatically defined by DEM, which, however, did not significantly influence the hydrological simulation. The boundaries defined by DEM and digital river network were more rational and scientific for hydrological simulation. Considering the topography, functional regionalization, and channel network, we adjusted the outlets of subbasins in the discretization process to avoid creating excessive subbasins. Long'anqiao and Shuangyang stations were

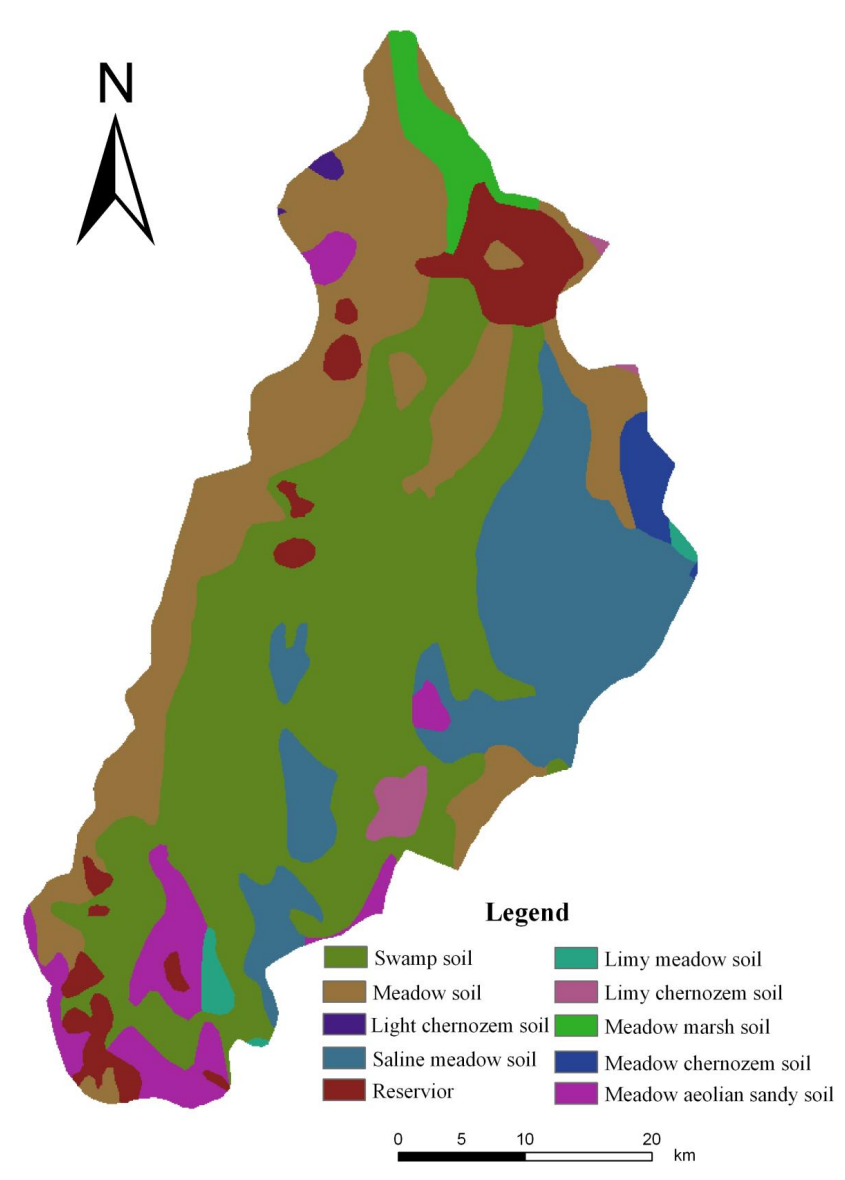

Fig. 2. Spatial distribution of soil types in the Zhalong wetland, Northeast China.

added to model as outlets of upstream draining watersheds. The Wenghai drainage engineering and Nenjiang River diversion projects were treated as point source discharges. The entire Zhalong wetland was subdivided into 14 subbasins, with a size ranging from 75 to $419 \mathrm{~km}^{2}$. Furthermore, land use and soil data were used to define multiple HRUs for each of the 14 subbasins by specifying thresholds for the land use and soil data, and 24 HRUs were created for the study area (Fig. 1).

\subsubsection{Treatment with wetlands}

Thousands of marshes and ponds exist in the Zhalong wetland. However, because of the model constraints and the complexity of describing each wetland, these wetlands were aggregated on the HRU basis, whereby the HEW concept (Wang et al., 2008) was adopted and only one wetland per HRU was considered. In this work, a total of 24 wetlands were modeled within the study area, and each of them represented a combined area and storage of all wetlands within the respective HRU. This large-scale simplification may lead to inaccuracies about the interactions of multiple wetlands, but the simulation of hydrological processes was deemed 


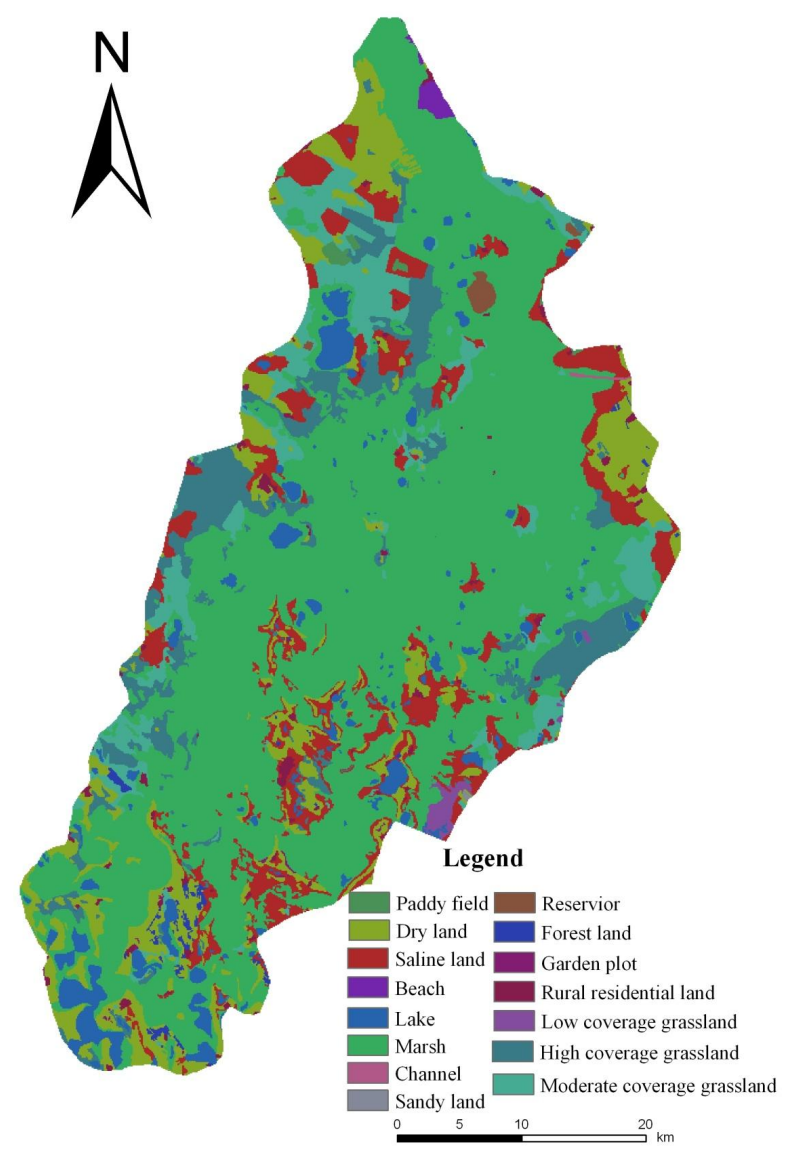

Fig. 3. Spatial distribution of land use types in the Zhalong wetland, Northeast China, in 2006.

satisfactory. Individual wetland water area, water depth and storage were determined by the DEM and ArcGIS analysis. It was assumed that surface-water depths of the wetlands within the same HRU were identical, mainly attributed to the same weather, topography, land use, soil type and channel characteristics.

The wetland in each HRU is partitioned into two types, an open wetland and a closed wetland. A parameter was used to determine the proportion of the open wetland and closed wetland in the HRU wetland. The open wetland was defined as having an outlet and would spill when the storage of the open wetland exceeded a spillage threshold. The spillage thresholds were estimated by the ArcGIS 3-D analyst (Surface Analysis-Area and Volume tool) module using the threshold of the water level in each HRU wetland. The closed wetland was defined as not having an outlet and spill would not occur. All closed wetlands were allowed to increase storage beyond their maximum to simulate the expansion of wetlands areas within the study area. The open water loses water through outflows whenever the storage exceeds the spillage threshold, while the closed wetland does not have outflow; the open and closed wetland all gain water from inflows and lose water mainly by evapotranspiration.

\subsubsection{Water balance calculation}

The model assumes that precipitation, evapotranspiration, soil seepage, wetland inflow and wetland outflow are the only significant hydrologic inputs and outputs and thus, there are no net contributions of water to wetlands from groundwater (Fig. 4). The dynamic water balance equation for the wetland is expressed as

$V_{T}=V_{T-1}+P+I-\mathrm{ET}-S-O$,

where $V_{T-1}$ and $V_{T}$ are the water storage of the wetland at the beginning and end of a day, respectively; $P, I$, ET, $S$ and $O$ denote precipitation, inflows (including upstream inflow and diverted water), evapotranspiration, soil seepage and channel outflow during the day, respectively. All variables in Eq. (1) have units of $\mathrm{m}^{3}$.

Water flows were routed into wetlands through drainage channels, using a user-defined fraction of inflows. The remaining water was transported along channels. In order to better analyze the wetland hydrological response to variable inflows, it is essential to couple the watershed model with the wetland module. In this study, the wetland module and watershed hydrological model are coupled through the upstream inflow in order to better represent the actual hydrological processes of the wetlands. Available streamflow were imported into the model by specified input files.

Water was lost from the wetland system through evapotranspiration, groundwater recharge and outflow. Evapotranspiration (ET) is the primary loss of open surface water and soil water. The actual evapotranspiration flux is mainly driven by water availability. In this study, water supply in the wetlands was sufficient and therefore, actual evapotranspiration was assumed to be approximately equal to potential evapotranspiration. Potential evapotranspiration was calculated with the Penman-Monteith equation. Groundwater recharge was set to vary directly with wetland water depth.

In addition, the open wetland releases water whenever the storage exceeds the spillage threshold, while the closed wetland does not have spillage. Spillage volumes from the open wetland, namely outflows, are directly proportional to the difference between the wetland storage and spillage threshold. Spillage volumes are routed into the channel network. The monthly spillage volume is different, as a result of winter freezing and spring unfreezing. We adopted outflow coefficient to reflect the effects of freezing and unfreezing on the outflow process for this area. Winter normally begins in November in the region, and water freezes slowly, and the outflow coefficient decreases. The outflow coefficient was assumed 0 during total freezing periods. The outflow coefficient was set to increase with increasing temperature and melting of snow and ice after April. The outflow coefficient was set for 1.0 when snow and ice totally melt. The wetland outflow is calculated as

$O=\left\{\begin{array}{cc}0 & V \leq V_{\text {spill }} \\ \mathrm{Ka} \cdot\left(V-V_{\text {spill }}\right) & V>V_{\text {spill }}\end{array}\right.$, 


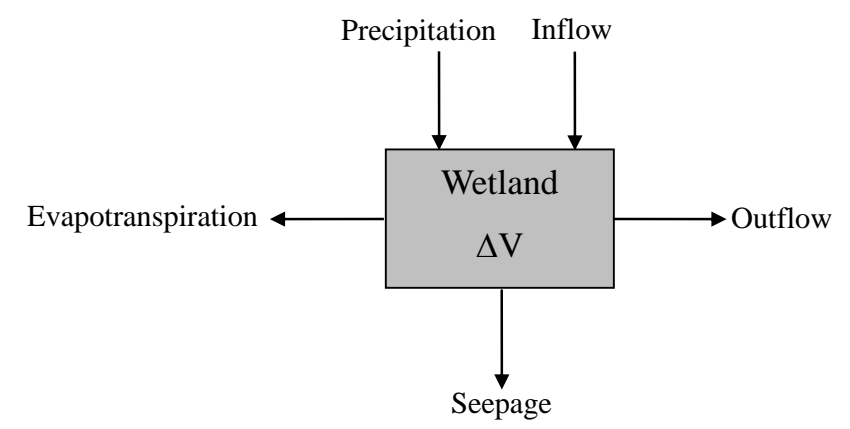

Fig. 4. A schematic diagram of hydrological processes in the Zalong wetland, Northeast China.

where $O$ is daily outflow of the wetland, Ka is the outflow coefficient, $V$ is the water storage of the open wetland, and $V_{\text {spill }}$ is the spillage threshold of the open wetland. All the variables, except for Ka that is dimensionless, have units of $\mathrm{m}^{3}$.

\section{Model calibration and validation}

Model runs were made for the years 1985-2006 with input data including DEM, weather parameters, soil parameters, land use/land cover data and the confirmations of wetlandrelated parameters. Based on the principle of reflecting the actual characteristics of wetlands, the fraction of wetlands on each HRU, fraction of closed wetland and open wetland, surface area of wetlands at maximum water levels, and storage of wetlands when filled to maximum water level were confirmed by ARCGIS spatial analysis of high resolution DEM. Parameters related to physical processes such as seepage coefficient were determined by the available research results in the Zhalong wetland. While the fraction of open wetland was adjusted during the calibration in order to attain to goodness of fit of wetland module.

Monthly streamflow data from 1987 to 1989 were used for model calibration and monthly streamflow from 2005 to 2006 were used for model validation. Model parameters SMTMP, SMFMX, TIMP, SURLAG, $\mathrm{CH} L 1$, CH_N1, CH_N2, SOL_AWC, ESCO, CH_K2 were identified as sensitive parameters by the sensitive analysis module of the ArcSWAT2005 model. SMTMP and TIMP reflect the effects of temperature on hydrological processes, especially in cold regions. SMFMX presents the influence of snowmelt conditions on runoff process. SURLAG, $\mathrm{CH} L \mathrm{~L} 1, \mathrm{CH} \_\mathrm{N} 1, \mathrm{CH} \_\mathrm{N} 2$, ESCO, and CH_K2 can affect the hydrological processes from the conditions of underlying surface and river channels. SOL_AWC is an important parameter that can affect soil water storage and movement. These parameters better reflect the underlying surface, weather and hydrological condition, and are sensitive to the simulation of hydrological processes (Vassilios et al., 1998). Considering the special soil physical properties, weather conditions and unique hydraulic characteristics of the wetlands, the calibration was primarily implemented by adjusting 4 watershed-level, 3 subbasin-level, and 3 HRU-level sensitive parameters. Table 1 summarizes the initial values, ranges and calibrated values of these 10 sensitive parameters.

The calibrated parameters of the SWAT model were then used to simulate monthly streamflow for the validation period. The accuracy of simulated values was examined using the Nash efficiency coefficient, $E_{\mathrm{ns}}$ (Nash and Sutcliffe, 1970), the coefficient of determination, $R^{2}$, and the performance virtue, PV (Eq. 3) (Wang and Melesse, 2005), as given below:

$\mathrm{PV}=\omega_{1} E_{\mathrm{ns}}+\omega_{2}\left(1-\left|D_{v j}\right|\right)$,

where $D_{v j}$ is the deviation of volume, $\omega_{1}$ and $\omega_{2}$ are the weights reflecting the priorities of simulating the silhouette and volume of the streamflow hydrograph observed at the station. A higher weight indicates a higher priority, and the weights must sum to 1 . The deviation of volume $\left(D_{v j}\right)$ is computed as

$D_{v j}=\frac{\sum_{i=1}^{n} Q_{p}-\sum_{i=1}^{n} Q_{m}}{\sum_{i=1}^{n} Q_{m}} \times 100 \%$,

where $Q_{p}$ and $Q_{m}$ are the simulated and observed streamflow, respectively, and $\mathrm{n}$ is the number of observed data. According to Wang and Melesse (2005), a simulation can be judged to have a "poor" performance when PV is less than 0.60 , an "acceptable" performance when PV is between 0.60 and 0.80 , and a "good" performance when PV is greater than 0.80 .

\section{Results and discussion}

\subsection{Goodness of fit of the model}

Table 2 shows indices of $\mathrm{PV}, E_{\mathrm{ns}}$, and $R^{2}$ for evaluating the simulated values during the calibration and validation periods. For the calibration period, all the indices indicated that monthly simulated streamflow were consistent with the observed values $\left(\mathrm{PV}>0.80, E_{\mathrm{ns}}>0.75\right)$. The simulated values reflected some ups and downs of annual streamflow (Fig. 5), and the model had a satisfactory performance in the simulation of streamflow. Whereas, there are certain differences between the simulated and observed streamflow, and the model performed satisfactorily for the validation period $(\mathrm{PV}>0.80$, $E_{\mathrm{ns}}>0.36$ ) (Fig. 6). Compared to the calibration period, the relatively poor prediction of the outlet streamflow in the validation period might be attributable to the simplification of the complex channel network and the altered outlets, as indicated by the underestimate of outflows. Meanwhile, the limited observed data also decreased the accuracy of simulated 
Table 1. Major model parameters and their settings for the Zalong wetland modeling.

\begin{tabular}{|c|c|c|c|c|}
\hline Parameter & Description & $\begin{array}{l}\text { Initial } \\
\text { values }\end{array}$ & Range & $\begin{array}{l}\text { Calibrated } \\
\text { values }\end{array}$ \\
\hline \multicolumn{5}{|l|}{ Watershed level } \\
\hline $\operatorname{SMTMP}\left({ }^{\circ}\right)$ & Snowmelt base temperature & 0.5 & $(-5.0,5.0)$ & 0.5 \\
\hline $\operatorname{SMFMX}\left(\mathrm{mm} \mathrm{H}_{2} \mathrm{O} /{ }^{\circ}\right.$-day $)$ & Maximum snowmelt rate & 4.5 & $(0.0,10.0)$ & 6.0 \\
\hline TIMP & Snowpack temperature lag factor & 1.0 & $(0.0,1.0)$ & 1.0 \\
\hline SURLAG (day) & Surface runoff lag coefficient & 4.0 & $(1.0,24.0)$ & 18.0 \\
\hline \multicolumn{5}{|l|}{ Subbasin level } \\
\hline $\mathrm{CH} L \mathrm{~L} 1(\mathrm{~km})$ & Longest tributary channel length in subbasin & $16.829 \sim 61.452$ & $(0.05,200)$ & $2.452 \sim 30.872$ \\
\hline $\mathrm{CH}+\mathrm{N} 1$ & Manning's $n$ value for the tributary channels & 0.014 & $(0.01,30)$ & 1.014 \\
\hline $\mathrm{CH} \_\mathrm{N} 2$ & Manning's $n$ value for the main channel & 0.014 & $(0.01,0.3)$ & 1.014 \\
\hline \multicolumn{5}{|l|}{ HRU level } \\
\hline SOL_AWC & Available water capacity of the soil layer & $0.04 \sim 0.18$ & $(0.00,1.00)$ & $0.04 \sim 0.45$ \\
\hline ESCO & Soil evaporation compensation factor & 0.95 & $(0.01,1.0)$ & 0.01 \\
\hline $\mathrm{CH} \_\mathrm{K} 2\left(\mathrm{~mm} \mathrm{~h}^{-1}\right)$ & Effective hydraulic conductivity in main channel allluvium & 0.00 & $(0.01,500.00)$ & $6.00 \sim 18.00$ \\
\hline
\end{tabular}

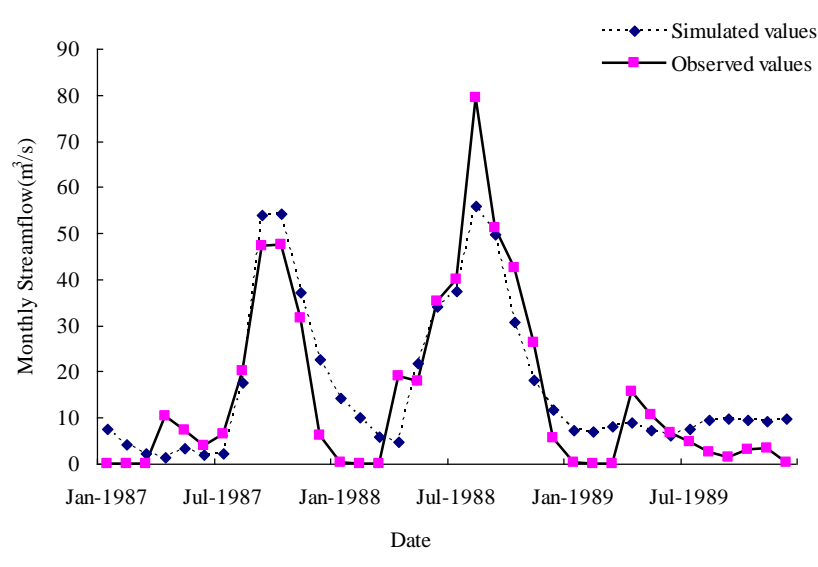

Fig. 5. Comparison between simulated and observed monthly outflow (Binzhouxian station) during the calibration period in the Zhalong wetland, Northeast China.

values during the validation period. Overall, the model better simulated the streamflow in the Zhalong wetland.

Modeling is a useful tool for the hydrological study in data-limited wetlands (M. N. Wang et al., 2010; Xu et al., 2008). With regard to the previous studies in the Zhalong wetland, Xu et al. (2008) conducted a hydrologic modeling study in the Zhalong wetland using a reservoir approach. Although their study provides information on hydrological cycle processes in the wetlands, the model is a semi-distributed model, ignoring the land surface hydrological processes in the preserve. In our study, we used a distributed hydrological model coupled with a wetland module to simulate several major components (e.g. water area, water storage, outflow, and water depth) in the surface hydrological processes of Zhalong wetland.
Table 2. Evaluation for simulation results of monthly outflow during calibration and validation periods in the Zhalong wetland, Northeast China.

\begin{tabular}{lccc}
\hline Simulation periods & $E_{\mathrm{ns}}$ & $R^{2}$ & $\mathrm{PV}$ \\
\hline Calibration period (1987-1989) & 0.86 & 0.89 & 0.86 \\
Validation period (2005-2006) & 0.66 & 0.66 & 0.82 \\
\hline
\end{tabular}

\subsection{Temporal change of open water area and storage}

Simulated monthly water area and storage for the years 1985-2006 are shown in Fig. 7. Simulated monthly water area is the sum of the open and closed wetland area, which is characterized by permanent or temporary inundation. Comparing the simulated water area with the results of satellite image interpretation of Landsat ${ }^{\mathrm{TM}}$ images of 8 periods during the period of 1986-2002 (Zhao et al., 2009; Gong et al., 2010; Tong et al., 2008), there was a relatively small difference $(<10 \%)$ in the water area. Simulated water area increased during wetter periods, but decreased during drier periods, mostly in the spring season. From the intra-annual variation of water area, the maximum monthly water area and storage usually occurred in October, not in August. The intra-annual variation of water area accorded with changing patterns of climatic and hydrological conditions. Because the upstream inflows and runoff generated in the HRUs were stored and cumulated in the wetlands during the summertime, the water area and storage increased and reached their maximums through October. In winter, the water area and storage decreased slightly, this was caused by freezing of water and largely reduced evapotranspiration. Generally, the minimums occurred in the month of June accompanying with high temperature, low precipitation, and strong evapotranspiration. 


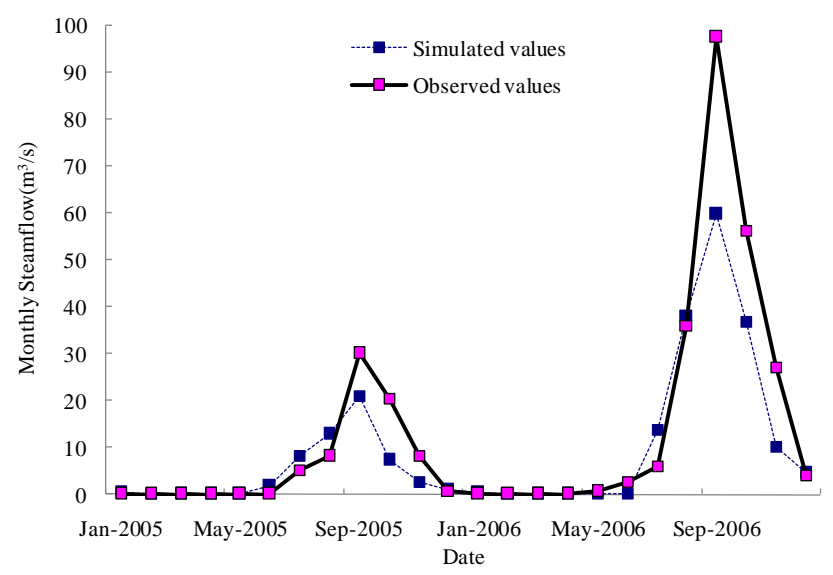

Fig. 6. Comparison between simulated and observed monthly outflow (Binzhouxian station) during the validation period in the Zhalong wetland, Northeast China.

The highest water area occurred in October 1985, where about $50 \%$ (i.e., $1145 \mathrm{~km}^{2}$ ) of the study area was inundated. The simulated water storage in the open and closed wetlands reached the maximum of $14 \times 10^{8} \mathrm{~m}^{3}$ at the same time. The open wetland released water whenever the storage exceeded the spillage threshold, while the closed wetland expanded the open water area to accommodate the excess water when the storage exceeded the maximum storage. There were apparent correlations between maximum of water area and maximum of water storage in the closed wetlands. Because of that, time synchronization of the maximums revealed that the closed wetland played a key role in the expansion of open water area and storage. The minimum value of simulated monthly water area happened in June 1996, with the water area of less than $200 \mathrm{~km}^{2}$, while the minimum water storage of the wetlands occurred in June 2003. The inconsistency in the occurrence of minimum water area and storage has occurred because of different relationships between water area and water storage in the individual wetlands. Water area and water storage of wetlands decreased during 1985-2001, which was in agreement with the findings by Gong et al. (2010). Since 2004, both open water area and water storage has increased, when compared with those in the 1990 s, due to the implementation of ecological water-supply engineering.

\subsection{Dynamics of outflow in the Zhalong wetland}

The simulated outflows in the Zhalong wetland from 1985 to 2006 are shown in Fig. 8. The interannual variation of outflow was highly variable, from zero in dry years (e.g. 1999 or 2001) to nearly $200 \mathrm{~m}^{3} \mathrm{~s}^{-1}$ in wet years, which was in agreement with the feature of the simulation results by $\mathrm{Xu}$ et al. (2008). In terms of monthly variation, the outflow was relatively small in the spring, due to the little effect of snowmelt on outflows. During the rainy season, the outflows increased with the conveyance of flows, generally reaching

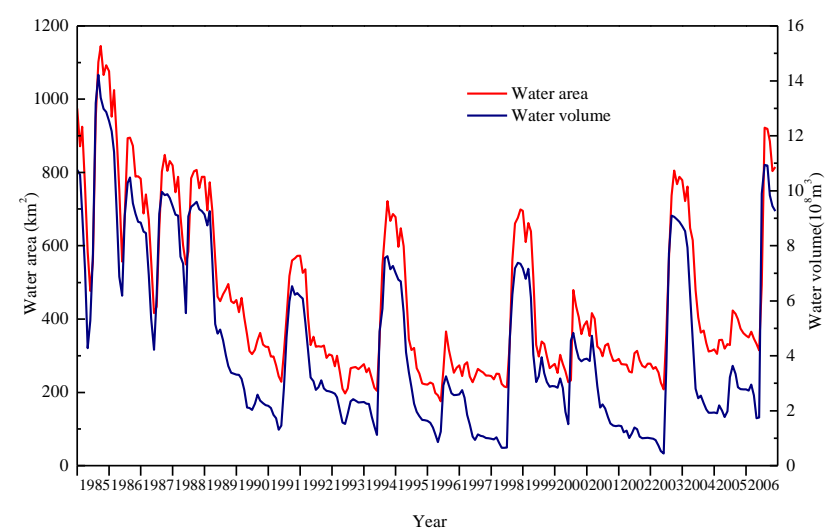

Fig. 7. Simulated monthly water area and water volume in the Zhalong wetland, Northeast China, during 1985-2006.

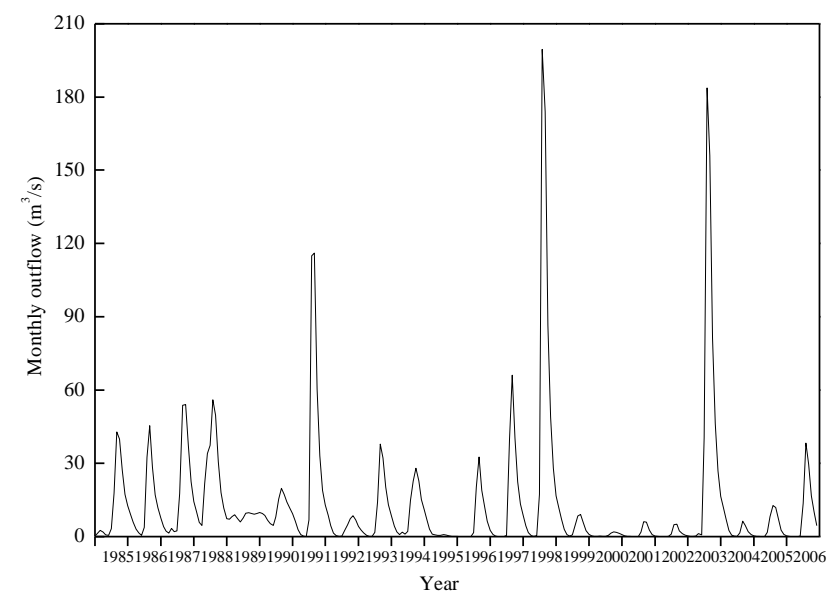

Fig. 8. Simulated monthly outflow in the Zhalong wetland, Northeast China, during 1985-2006.

their maximum in September or October. After that, the outflows decreased and arrived at zero when waters were totally frozen. On the whole, simulated outflows were in accordance with natural conditions. Maximum water area and storage corresponded to the maximum outflow, which was largely affected by wetland hydrological characteristics of conveyance, storage and retention.

\subsection{Variation of water depth in wetlands}

Water depth is a key factor affecting wetland ecosystem function and health (Zhong et al., 2005). The central zone of the Zhalong wetland, as a typical wetland environment, is the main habitat for waterfowls. Therefore, we focused our analysis on the variability of water depth in this zone.

Measured wetland water levels from 3 plots in the central zone were available for evaluating the simulated water depths in 2005 and 2006. Simulated water depth in each subbasin (subbasin 5, 7, and 8) in the central zone equals to 


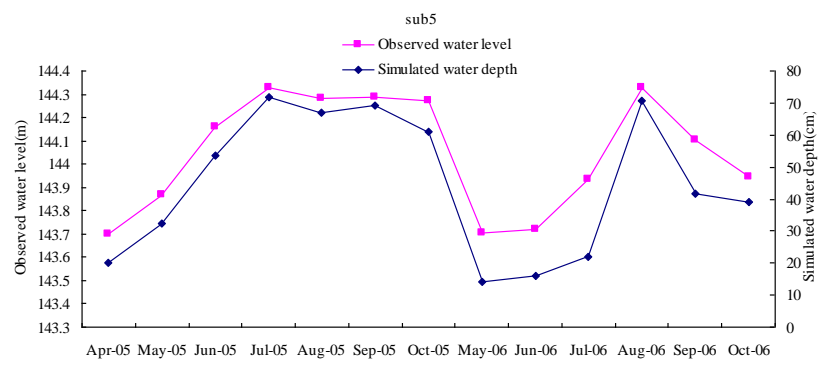

Date

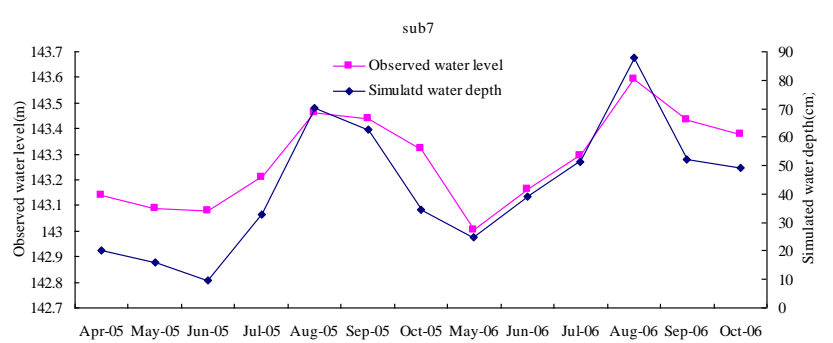

Date

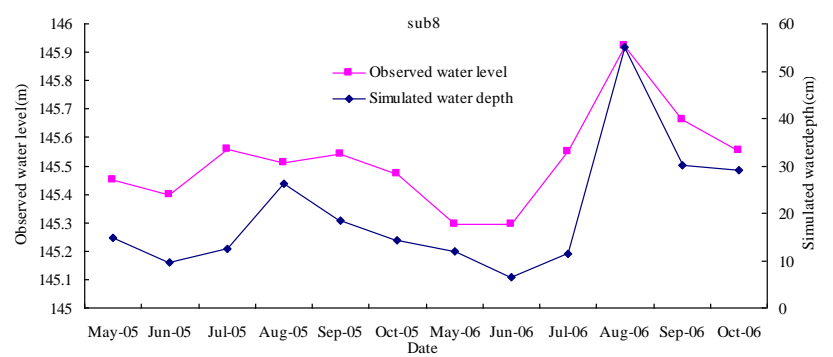

Fig. 9. Comparison between observed water level and simulated water depth in subbasins of the central zone in the Zhalong wetland, Northeast China, for 2005 and 2006.

the average value of wetlands surface-water depth in their respective subbasin. In general, the highest monthly water depth occurred in August, while the lowest appeared in June. Figure 9 compares the observed surface-water level with the simulated water depth in the same HRUs. There was good agreement between the simulated water depth and observed water level, though with a slight difference in ranges, showing that the model is credible for the simulation of hydrological components in the Zalong wetland. The differences between simulated water depth and observed water level of different subbasins were varied. Due to the fact that the observed water level was acquired from the specific field, and the simulated water depth was the average value of wetlands surface-water depth in subbasin 8 which was the biggest subbasin in the Zhalong wetland, the results of subbasin 8 were not as good as the others.

Figure 10 presents the simulated water depth in the central zone, including subbasin 5, 7, and 8. Regarding interannual variation, the water depth decreased from the late 1980s to the early 1990s, influenced by the decrease of inflows and increased temperature. In the 1990s, water depth in the central
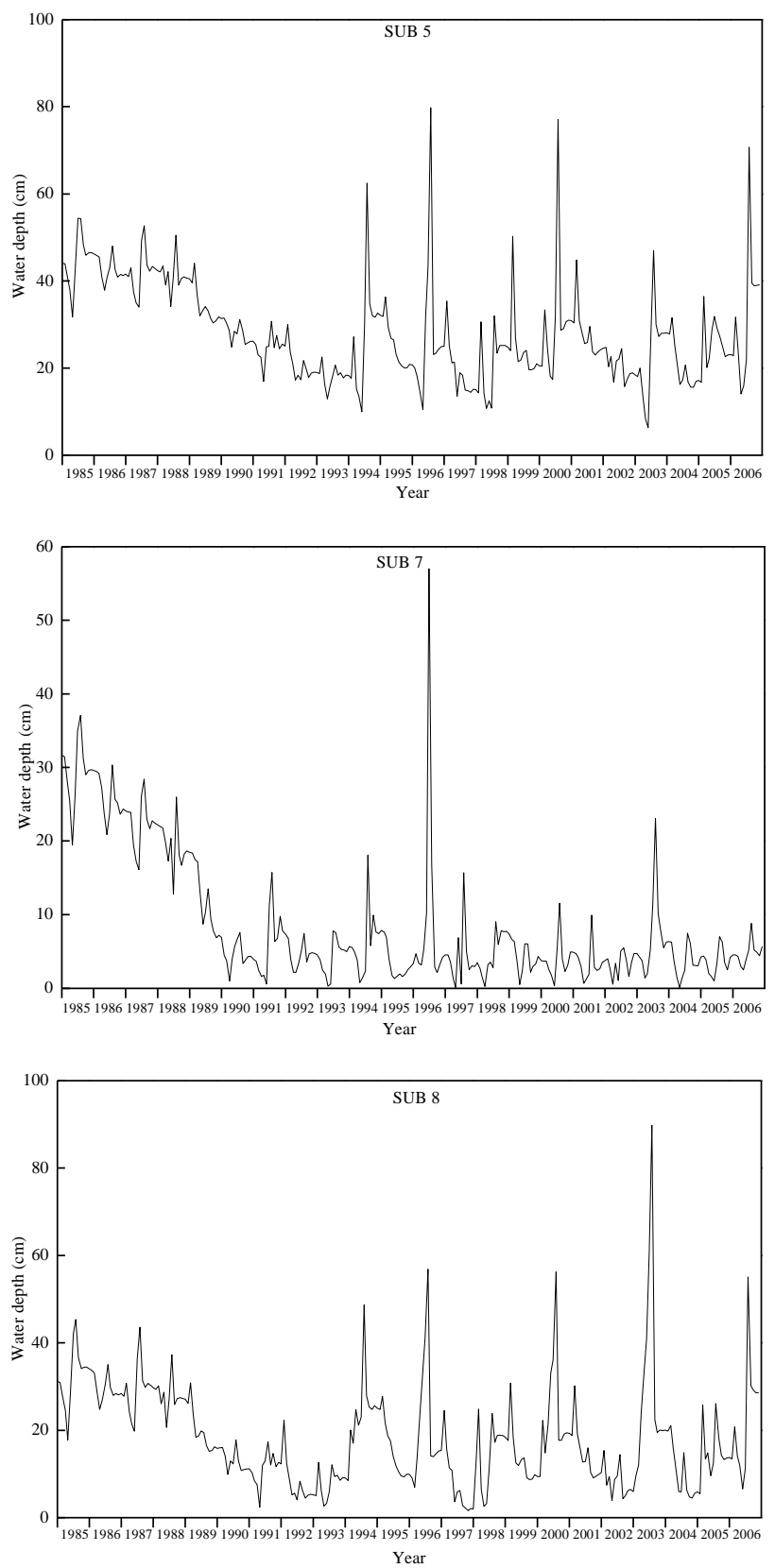

Fig. 10. Simulated surface-water depth in different subbasins of central zone in the Zhalong wetland, Northeast China, for 1985 and 2006.

zone had fluctuant variations in the control of natural precipitation. Since 2001, the water level rose and the fluctuation decreased under the influence of diverted water from the Nenjiang River. The variation in water depth in the central zone corresponded to the actual conditions that were influenced by wetland inflows from precipitation, upstream rivers and artificial water supply by river diversion. From the late 1980s, increased water use in agriculture and the social economy caused the decrease of inflows from upstream rivers 
and Nenjiang River, altering the hydrological processes in the Zhalong wetland. The decadal variations of water depth in wetlands is in agreement with the description by Tong et al. (2008).

\section{Conclusions}

In this study, a wetland module was developed and incorporated with the SWAT model to simulate hydrological processes for the Zhalong wetland in Northeast China. The module considered the flow exchange between wetland and river channels and aggregated wetlands into groups to represent the hydrological linkage between wetland areas and upland areas within the associated watersheds. The modified SWAT modeling system was calibrated and validated with field measurements including streamflow and water level. The simulation results show that the model with the modified module has a good performance in reconstructing wetland hydrological processes, which contributes to understanding the variation of hydrological components and functions of the Zhalong wetland with limited monitoring data. The simulation study reveals considerable variation of wetland hydrological components in the Zhalong wetland as a whole, which reflects the strong influence of the upstream river basin on the wetland hydrological regime. The variations of water area, water storage and outflow in the study area are largely affected by the wetland hydrological functions of conveyance, storage and retention, while water depth in the central zone is influenced by the inflows. Therefore, this study build a foundation for estimating ecological water requirements for the wetlands, helping develop strategies and plans for water resources management within the river basin, which will promote the sustainable and harmonious development of water resources, social economy and ecological protection, especially in the river basin with important wetland nature reserves.

Acknowledgements. This study was jointly financed by the National Basic Research Program of China (973 Program) (2010CB428404), the National Nature Science Foundation of China (41101034) and the Knowledge Innovation Program of the Chinese Academy of Sciences (KZCX2-YW-Q06-2). We are grateful to the Qiqihar Hydrology Bureau of Heilongjiang Province and the China Meteorological Administration for providing us with some of the streamflow and climatic data used in this study that made this work possible.

Edited by: N. Verhoest

\section{References}

Acreman, M. C., Blake, J. K., Booker, D. J., Harding, R. J., Reynard, N., Mountford, J. O., and Stratford, C. J.: A simple framework for evaluating regional wetland ecohydrological response to climate change with case studies from Great Britain, Ecohydrology, 2, 1-17, 2009.

Arnold, J. G, Srinivasan, R., Muttiah, R. S., and Williams, J. R.: Large area hydrologic modeling and assessment - Part 1: Model development, J. Am. Water. Resour. Assoc., 34, 73-89, 1998.

Arnold, J. G., Allen, P. M., and Morgan, D. S.: Hydrologic model for design and constructed wetlands, Wetlands, 21, 1-16, 2001.

Bradley, C.: Simulation of the annual water table dynamics of a floodplain wetland, Narborough Bog, UK, J. Hydrol., 261, 150172, 2002.

Burkett, V. R. and Kusler, J.: Climate change: potential impacts and interactions in wetlands of the United States, J. Am. Water. Resour. Assoc., 36, 313-320, 2000.

Carey, W. P. and Simon, A.: Physical basis and potential estimation techniques for soil erosion parameters in the PrecipitationRunoff Modeling System (PRMS), US Geological Survey WaterResources Investigations Report 82-4218, 32 pp., 1984.

Feng, X. Q. and Zhang, G. X.: Analysis of the hydrologic regime affected by natural and human factors over the Zhalong Wetland, Resour. Sci., 32, 2316-2323, 2010 (in Chinese).

Feng, X. Q., Zhang, G. X., and Yin, X. R.: Study on the hydrological responses to climate change in Wuyuer River Basin on the SWAT model, Prog. Geogr., 29, 827-832, 2010 (in Chinese).

Feng, X. Q., Zhang, G. X., and Yin, X. R.: Hydrological responses to climate change in Nenjiang River Basin, Northeastern China, Water Resour. Manage., 25, 677-689, 2011 (in Chinese).

Gong, P., Niu, Z. G., Cheng, X., Zhao, K. Y., Zhou, D. M., Guo, J. H., Liang, L., Wang, X. F., Li, D. D., Huang, H. B., Wang, Y., Wang, K., Li, W. N., Wang, X. W., Ying, Q., Yang, Z. Z., Ye, Y. F., Li, Z., Zhuang, D. F., Chi, Y. B., Zhou, H. Z., and Yan, J.: China's wetland change (1990-2000) determined by remote sensing, Sci. China. Ser. D, 40, 768-775, 2010 (in Chinese).

Han, M., Sun, Y. N., and Xu, S. G.: Characteristics and driving factors of marsh changes in Zhalong wetland of China, Environ. Monitor. Assess., 127, 363-381, 2007 (in Chinese).

Krecek, J. and Haigh, M.: Environmental role of wetlands in headwaters, Springer, Netherlands, 2006.

Li, F., Lu, C. H., Yang, H. J., and Yang, S. Z.: Community diversity about breeding birds in reed marsh of Zhalong Natural Reserve, J. Northeast. For. Univ., 26, 68-72, 1998 (in Chinese).

Li, F., Yang, H. J., Zhang, H. H., and Gao, Z. X.: The nest-site selection by red-crown crane in the Zhalong Wetland, J. Northeast. For. Univ., 27, 57-60, 1999 (in Chinese).

Liu, D. Q. and Xu, S. G.: Analysis of water balance in Zhalong Wetland, J. Nat. Resour., 21, 341-348, 2006 (in Chinese).

Milzow, C., Burg, V., and Kinzelbach, W.: Estimating future ecoregion distributions within the Okavango Delta Wetlands based on hydrological simulations and future climate and development scenarios, J. Hydrol., 381, 89-100, 2010.

Mitsch, W. J. and Gosselink, J. G.: Wetlands, John Wiley \& Sons, New York, 2000.

Moradkhani, H., Barid, R. G., and Wherry, S. A.: Assessment of climate change impact on floodplain and hydrologic ecotones, J. Hydrol., 395, 264-278, 2010. 
Nash, J. E. and Sutcliffe, J. V.: River forecasting through conceptual models: Part I. A discussion of principles, J. Hydrol., 10, 282290, 1970.

Neitsch, S. L., Arnold, J. G., Kiniry, J. R., and Williams, J. R.: Soil and Water Assessment Tool: Theoretical Documentation (version 2000). USDA-ARS Grassland, Soil and Water Research Laboratory, Blackland Research Center, Texas Agricultural Experiment Station, Temple, TX, 2002.

OECD.: Guidelines for aid agencies for improved conservation and sustainable use of tropical and sub-tropicak wetland, Organisation for Economic Cooperation and Development Assistance Committee: Guidelines on Aid and Environment 9, 69pp., 1996.

Padmanabhan, G. and Bengtson, M. L.: Assessing the influence of wetlands on flooding, In: Proceedings of the ASCE Wetlands Engineering and River Restoration, edited by: Hayes, D. F., ASCE, Reston, VA, 2001.

Qiu, F. C., Lin, B. Q., Cai, Y. J., Liu, S. L., and Pang, S. L.: Observation on Siberian white crane migration in spring in Zhalong Nature Reserve, J. Northeast. For. Univ., 33, 103-105, 2005 (in Chinese).

Tong, S. Z., Lu, X. G., Su, L. Y., Jiang, M., and Yao, Y. L.: Changing process and the impact factors of wetland ecosystem in Zhalong Wetland, Wetl. Sci., 6, 179-184, 2008 (in Chinese).

Tong, S. Z., Lu, X. G., Zhang, Z. S., and Song, X. L.: Characteristics of runoff variation in Wuyuer-Shuangyang River watersheds and their influences on Zhalong Wetlands (1956-2000), Northeast China, J. Food Agric. Environ., 10, 907-913, 2012.

USACE, HEC.: Hydrologic analysis of ungaged watersheds using HEC-1, US Army Corps of Engineers Hydrologic Engineering Center, TD-15, Davis, CA, USA, 1982.

Vassilios, A. T., David, L. J., and Paul, J. T.: Hydrodynamic modeling of wetlands for flood detention, Water. Resour. Manage., 12, 251-269, 1998.

Vining, K. C.: Simulation of streamflow and wetland storage, Starkweather Coulee Subbasin, North Dakota, water years 1981-98, Water Resources Investigations Report 02-4113, 2002.

Wang, H., Xu, S. G., and Sun, L. S.: The prediction on reed swamp evapotranspiration in Zhalong wetland, China, Acta. Ecol. Sin., 26, 1352-1358, 2006 (in Chinese).
Wang, L. and Zhang, G. X.: Hydrochemical interaction between surface water and groundwater in Zhalong Wetland, Wetl. Sci., 5, 166-173, 2007 (in Chinese).

Wang, M. N., Qin, D. Y., Lu, C. Y., and Li, Y. P.: Modeling anthropogenic impacts and hydrological processes on a wetland in China, Water. Resour. Manage., 24, 2743-2757, 2010.

Wang, X. X. and Melesse, A. M.: Evaluation of the SWAT model's snowmelt hydrology in a northwestern Minnesota watershed, T. ASABE., 48, 1359-1376, 2005.

Wang, X. X., Yang, W. H., and Melesse, A. M.: Using hydrologic equivalent wetland concept within SWAT to estimate streamflow in watersheds with numerous wetlands, T. ASABE., 51, 55-72, 2008.

Wang, X. X., Shang, S. Y., Qu, Z. Y., Liu, T. X., Melesse, A. M., and Yang, W. H.: Simulated wetland conservation-restoration effects on water quantity and quality at watershed scale, J. Environ. Manage., 91, 1511-1525, 2010.

Wu, C. S.: Research and management of natural resources in Zhalong National Nature Preserve, Press of Northeast Forestry University, Harbin, 1999.

Xu, S. G., Liu, D. Q., and Tang, X. L.: Modeling hydrological cycle system in Zhalong wetland based on reservoir model concept, Adv. Water. Sci., 19, 36-42, 2008 (in Chinese).

Yin, Z. Q., Qin, X. G., Liu, J. Q., and Qiu, S. W.: Formation background of the Zhalong Wetland and its eco-environmental significance, Prog. Geogr., 25, 32-38, 2006 (in Chinese).

Zhao, X. J., Yang, F. H., Liu, Y. X., Zhang, L., and Wang, S.: Analysis on utilization changing of Zhalong Wetland, Geomat. Spat. Inf Technol., 32, 54-57, 2009 (in Chinese).

Zhong, P., Yang, Z. F., Cui, B. S., and Liu, J. L.: Studies on water resource requirement for eco-environmental use of the Baiyangdian Wetland, Acta Sci. Circumst., 25, 1119-1126, 2005 (in Chinese).

Zhou, L. F., Xu, S. G., and Liu, D. Q.: The water cycling characteristics of Zhalong wetland and its water resource management, J. Hydroelectric. Eng., 27, 56-61, 2008 (in Chinese). 